fall-off. Front-projection, unlike rear, can be employed on scrim-like transparent surfaces. In fact, front-projection is the cheaper approach to building a theatre, because there is no need whatsoever for back stage space.

Beyond this, the planners of a new theatre should not think only in motion-picture terms, however advanced. If Appia's postulate for the first transformation of the theatre in this century was the concept of Living Space -the actor's living body surrounded by organic space-then the second transformation must be the conversion of static space into dynamic space.

Erwin M. Feber Metropolitan Opera New York City

\section{THE EDITORS:}

It's good to see all those opinions side by side in the architectural issue [T39, Spring, 1968]. I am disappointed, however, that Richard Schechner's manifesto, the "6 Axioms" (for all its patient work) has so little to do with the creating potential of architecture.

If the real point of environmental theatre is its use of "totally transformed or formed spaces," then it's really unnecessary to have all those pictures of turning building shapes and words about "a consummatory completion of the cycle."

The tough question is whether architecture is impotent in the face of the 6 axioms. Obviously, all that fun in the bus terminal depends upon the fact of its use as a transportation center. The fact that it looks so drab and conditions people to avoid awareness is part of the game. There's a conscious choice on Schechner's part to exploit its reality as a bus terminal as part of the environmental piece. To construct a theatre specifically for this piece by making a bus terminal would also be a conscious choice, but one that reaches too far back into time and makes the whole event a ridiculous art of super-institutionalization.

Any architecture worth the dislocation of light and air it causes must be based upon the need to intensify some human activity. After all, you can catch a bus in the street without any assistance from a building. The environmental theatre pieces you mention

\section{RE-OPENING IN SEPTEMBER!}

\author{
Riverside Productions \\ presents
}

the

DMZ

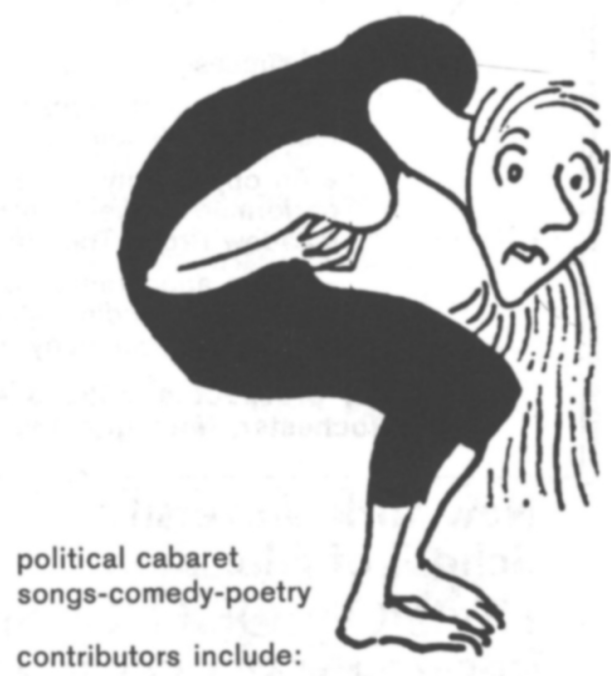

Eric Bentley, Wolf Biermann, Arnold Black, Albert Bermel, Jules Feiffer, Robert Hivnor, Jean-Claude van Itallie, Robert Lowell, Eve Merriam, Richard M. Elman, Richard Peaslee, Jerome Clegg \& many others.

\section{staged by Isaiah Sheffer}

every night except Monday at $9 \& 11 \mathrm{pm}$

Admission $\$ 2$ Sunday-Thursday

$\$ 2.50$ Friday and Saturday

no minimum-food and drink at reasonable prices

\section{the DMZ}

Broadway \& 111th St. New York City R1 90200 


\section{קב}

\section{The Academy of Dramatic Art of Oakland University}

Director: John Fernald, Artistic Director, Meadow Brook Theatre, Director of the Royal Academy of Dramatic Art, London, 1955 to 1965.

\begin{tabular}{|c|c|c|}
\hline Auditions & $\begin{array}{l}\text { October } 1968 \\
\text { January } 1969 \\
\text { May } 1969\end{array}$ & $\begin{array}{l}\text { for entry in January } 1969 \\
\text { for entry in April } 1969 \\
\text { for entry in October } 1969\end{array}$ \\
\hline
\end{tabular}

To successful candidates the Academy offers:

- Two years of intensive professional training in all acting techniques, leading to a Diploma in Acting.

- An opportunity to see many of the world's great plays performed by the John Fernald Repertory Company in the Meadow Brook Theatre.

- Public appearances during the second year of training, and to outstanding students the chance of joining the professional company at Meadow Brook.

For prospectus write to ADA (D.R.), Oakland University, Rochester, Michigan 48063.

New York University

School of Education

DIVISION OF ENGLISH EDUCATION, SPEECH, AND EDUCATIONAL THEATRE

offers

- specialized study in educational theatre

- new and extensive courses in creative dramatics and children's theatre

- opportunities for graduate work in educational theatre research on all levels-primary, secondary, and college

- production work in adult and young people's theatre B.S., A.M., Ed.D., and Ph.D. degrees in Educational Theatre

For information; write:

MARIAN PRIMONT

Head, Program in Educational Theatre

NEW YORK UNIVERSITY

Washington Square

New York, N.Y. 10003 


\section{LETTERS}

deliberately exploit the fact that they take place out of normal context. The theatre is made into a living room, or the subway is made into a theatre, etc.

It seems, to be straight about this, that your issue on theatre architecture really should have a 7th axiom: The irrelevancy of architecturally designed space to environmental theatre. I still wouldn't agree this is true, but I would prefer your saying all this straight out to having a long academic introduction-manifesto to a bunch of articles which for the most part have no relevance to what you are saying.

Then, I could enjoy writing you a letter about why I think architecture is essential to environmental theatre.

\section{Hugb Hardy \\ New York City}

Note: Mr. Hardy is the chairman of the Theatre Architecture Committee of the US. Institute for Theatre Technology. His article, "Designing Random Focus," was publisbed in the architectural/environmental issue of $T D R$.

\section{THE EDITORS:}

From Volume 1, 1956, to 11, 1967, you were content to be known as Tulane Drama Review.

As of Volume 12, 1967, your cover reads $t d r$; the drama review. Dreadful. Do you plan to be known and permanently catalogued under that title or will you, as I suspect, jettison the $t d r$ and appear only as The Drama Review?

I suspect the latter but don't know; and I would like to bewail, not your change of title, but your own apparent perplexity.

If publishers and the William Morrises in the Layout Department knew the amount of frustration inflicted by this sort of shillyshallying, they would clearly announce their planned changes in title to irascible librarians. A cordial pox vobiscum.

Paul W. Boytinck

Ellen Clarke Bertrand Library Lewisburg, Pa.

$A$ rose is a rose is a rose. $-E d$.
THE

JOURNAL

OF

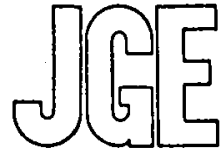

GENERAL EDUCATION

FALL 1968

CRAFT AND INTENTION

IN JAMES AGEE'S

A DEATH IN THE FAMILY

JAMES J. SOSNOSKI

STUDENTS AND

CIVIL DISOBEDIENCE

EDWARD JOSEPH SHOBEN, JR.

THE PENNSYLVANIA STATE

UNIVERSITY PRESS

UNIVERSITY PARIS, PA., 16802

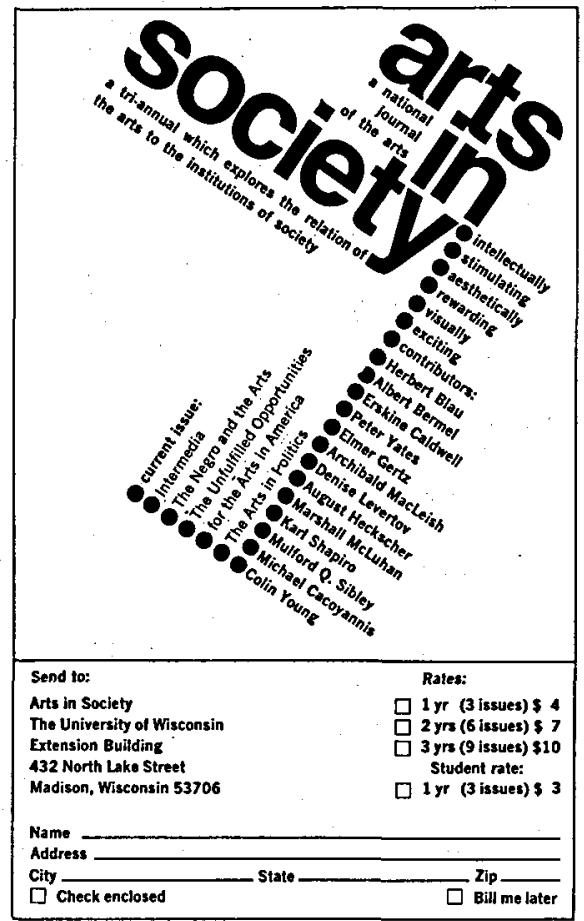

